KA U KO KYYR Ö

\title{
Poliittiset allegoriat suomenkielisessä runoudessa helmikuun manifestista suurlakkoon
}

Allegorinen KUVA JA KeRTomus ovat kaikkina aikoina olleet ensi sijassa sorretun ja aseettoman taistelukeinona väkivaltaa vastaan. Tästä johtuu, ettei mikään runouden kielikuvista ole siinä määrin kuin' allegoria sidottu aikaansa ja ympäristöönsä. Samasta syystä myös allegorioiden olemassaolon toteaminen ja niiden tulkinta on hyvin vaikeaa; erehtymismahdollisuudet ovat rajattomat ja lisääntyvät edelleen ajallisen välimatkan kasvaessa. Eräässä teoksessani olen kertonut tästä kuvaavan esimerkin: Ranskan ensimmäisen keisarikunnan aikana (v. 1805) Napoleonin poliisipäällikkö Fouché oli läsnä teatterinäytännössä, jossa esitettiin Racinen näytelmä Athalie (kirj. 1689). Epäluuloinen Fouché luuli huomanneensa tässä toistasataa vuotta aikaisemmin kirjoitetussa näytelmässä sopimattomia ja kapinahenkeä todistavia viittailuja herraansa Napoleonia vastaan ja määräsi näytelmän kirjoittajan viipymättä vangittavaksi.1

Ylläoleva esimerkki on mielestäni oivallinen kuvaamaan niitä tulkinta- ja dateerausvaikeuksia, jotka kohtaavat erityisesti poliittisten allegoriain selvittämisyrityksiä. Ei ole suinkaan varmaa, että allegorian tarkoitus on ilman muuta kaikille selvä edes allegorian syntymähetkellä. Kautta aikojen ovat sensorit ja syyttäjäviranomaiset seisoneet avuttomina allegorioiden edessä: ne voivat tarkoittaa jotakin valtiollisesti tai uskonnollisesti sopimatonta tai kiellettyä, todennäköisesti ne sitä tarkoittavatkin, mutta toisaalta — ne voidaan tulkita toisellakin tavalla katsomalla mahdollista allegorista sisältöä sormien lävitse ja ymmärtämällä runo (kertomus, romaani,

1 Kauko Kyyrö, Madame de Maintenon et Jean Racine, 1949, s. 104. 
maalaus jne.) kirjaimen mukaan ilman minkäänlaisia sala-ajatuksia. Tavallisimmin sensuurin onkin täytynyt tyytyä viimeksimainittuun ratkaisuun - ilmeisesti usein katkerin mielin. Toisena vaihtoehtona olisi vain tehdä poliittisia marttyyreja, mikä olisi sitäkin vaarallisempaa.

Niinpä tämän tutkielman tekijä ei olekaan voinut operoida täsmällisillä suureilla. Materiaalina on 148 lyyrillistä, osaksi lyyrilliseepillistä runoa, jotka kirjoittajan subjektiivisen mielipiteen mukaan ovat poliittis-allegorisia tai poliittista allegoriikkaa sisältäviä. Ne on tiettävästi kirjoitettu otsikossa mainittujen aikarajojen sisällä ja jakaantuvat 21 runoilijan ja 32 kokoelman kesken. Lukuun on laskettu mukaan myös sanoma- ja aikakauslehdistöstä poimitut kahdeksan runoa, jotka tiettävästi eivät sisälly mihinkään kokoelmaan.2 Mukaan on otettu ainoastaan sellaiset runot, joiden poliittinen allegoriikka kirjoittajan mielestä on ilmeinen. Eräät niistä ovat liitettävissä johonkin täsmälliseen tapahtumaan tai aikaan, sillä muutamilla vuosisadan vaihteen runoilijoilla näyttää olleen tapana merkitä ajankohtaisen - mutta vain ajankohtaisen - runonsa päiväys runon otsikon alle tai runon loppuun. Eräät ovat tyytyneet pelkkään vuosilukuun; toiset taas oyat liittäneet mukaan kuukauden ja jopa päivämääränkin. Tällaisten runojen kohdalla kirjoittaja tuntee liikkuvansa tukevalla maaperällä. Samaa on sanottava niistä tapauksista, joissa runoilijan elämänkertoja tietää erilaisiin todistuskappaleisiin vedoten täsmentää runon syntyhetken ja syntymisen taustan. Myös vuosi, jolloin runo tai kokoelma ilmestyi painosta, on eräänlainen osatodistus. Ainakin se osoittaa sen ajankohdan, minkä jälkeen runo ei ole saattanut syntyä. Mutta valitettavan usein kirjoittajan on ollut todettava, ettei runoa, joka kirjoittajasta on ilmeisesti poliittis-allegorinen, voida yhdistää mihinkään täsmälliseen aikaan eikä poliittisen sorron ilmiöön. Ajasta ja kohteesta irrotet-

2 Tämä tarkoittaa tilapäisrunoja, joiden runoilijat eivät koskaan päässeet kokoelmaan asti. Yleisenä sääntönä näyttää olevan, että sanoma- tai aikakaus_ lehdessä painettu runo ilmestyy sellaisenaan tai muokattuna uudelleen ao. runoilijan seuraavassa kokoelmassa. Tässä yhteydessä sopinee huomauttaa, että pilalehtien tutkiminen poliittis-allegorista runoutta silmällä pitäen on tuottanut erittäin laihan tuloksen (2 runoa). Joko pilalehdet olivat sensuurin silmätikkuina, tai sitten asian pyhyys esti viemästä sitä pilalehtien palstoille. Poliittisallegorisia pilakuvia on sen sijaan runsaasti. 
tuna jää jäljelle vain runon isänmaallinen henki, joka voimakkaasti julistaa vastalauseensa sortoa ja oikeudettomuutta vastaan.

Kirjoittajan mielessä on väikkynyt ajatus tutkia kaikkien sortovuosiemme polịttista r'unoutta. Tästä ajatuksesta on kuitenkin ollut luovuttava. Syynä on se, että vuoden 1905 suurlakko muutti maamme sisäisen rintamanasettelun kokonaan toiseksi. Ennen suurlakkoa näyttää sorron vastustajien rintama olleen rikkumattoman kiinteä ja yksimielinen, joskin aktiivisuuden eri asteet ovat selvästi havaittavissa. Mutta lakon jälkeen rintama repeää. Työväestö ja sen mukana ns. työläiskirjailijat ja työläiskirjallisuus näkivät kahden sortajan olemassaolon, ulkonaisen ja sisäisen, ja kaikkein useimmissa tapauksissa on puolen vuosisadan kuluttua mahdotonta sanoa, kohdistuivatiko työläisrunoilijan uhma, viha ja raivo tsaarinvaltaan ja sen kätyreihin vai oman maan toisinajatteleviin, jotka usein olivat parempiosaisia, "sortajia". Tästä syystä kirjoittaja on rajoittanut esityksensä vain ensimmäiseen sortokauteen eli aikaan helmikuun manifestista suurlakkoon (helmik. 1899_lokak. 1905).

Sensuuri on allegorisen runouden - ja kaiken allegoriikan äiti, mutta sellainen, joka tarun äidin tavoin pyrkii syömään omat lapsensa. Siksi lyhyt silmäys sensuurilaitoksen kehitykseen ja tilaan tutkielmamme ajankohtana Suomessa lienee paikallaan.

Painotuotteiden ennakkosensuuri maassamme perustui vuoden 1867 asetukseen. Sensuuriolot olivat Suomessa kutakuinkin siedettävät melkein vuosisadan loppuun asti, mutta v. 1899, jolloin venäläistämistoiminta ja sen synnyttämä vastarinta kohosi täyteen voimaansa, kävi painotuotteiden julkaiseminen hyvin vaikeaksi. Eräs aikalainen kuvaa virkavallan rettelöintiä sellaiseksi, "jommoista ei ennen oltu tunnettukaan Suomessa ja tuskin missään muussakaan maassa". 3 Mainitusta vuodesta lähtien kenraalikuvernöörillä oli rinnallaan neuvotteleva sensuurikomitea, jonka jäsenet hän itse määräsi. Nämä olivat venäläisiä miehiä, joista tuskin ainoakaan taisi maan kieliä, puhumattakaan siitä, että he olisivat tunteneet Suomen lait ja oikeudet:4 Uuden vuosisadan alkaessa painetun sanan valvonta kiristyi äärimmilleen ja jatkui yhtä johdonmukaisen armottomana aina vuoden 1904 syksyyn, jolloin muuttuneet olosuhteet sai-

\footnotetext{
3 Santeri Ivalo, Sensuurioloista Suomessa. Oma Maa II.

4 Vrt. esim. J. V. Miesmaa, Ennakkosensuurin pimeimmiltä ajoilta.
} 
vat aikaan eräitä vähäisiä lievennyksiä. Vasta suurlakko pyyhkäisi pois ennakkosensuurin ja muut vapaata sanaa kahlitsevat rajoitukset. Kenraalikuvernööri Seynin ajan sensuuri seuraavalla vuosikymmenellä ei enää kuulu tämän tutkielman piiriin.

Luonnollista oli, että sanomalehdistö sai vastaanottaa sensuurin ensimmäiset iskut ja raskaimman paineen. Olihan se ryhtynyt sortokauden alkaessa rohkeasti ja suoraselkäisesti arvostelemaan niitä laittomia toimenpiteitä, joiden tarkoituksena oli valtiollisen ja kansallisen erikoisasemamme tuhoaminen. Niinpä se joutui maksamaan raskaan veron painoesteinä sekä määräaikaisina ja ikuisina lakkauttamisina. Kuvaavat ovat seuraavat luvut: v. 1899 ilmestyi Suomessa 210 lehteä, mutta v. 1902 enää vain 85.5 Ellei lakkauttamisen syynä voitu osoittaa mitään varsinaista "rikosta", riitti siksi pelkästään lehden "yleinen vahingollinen suunta".6 Kirjoittaja pitää tätä seikkaa syynä siihen, että hän tätä tutkielmaa varten materiaalia kerätessään on sanoma- ja aikakauslehdistöstä tehnyt vain hyvin harvoja löytöjä, jotka nekin keskittyvät käsiteltävänä olevan ajanjakson alkuun.

Taivaanrannan pimetessä runous - ja kaunokirjallisuus yleensä - tunsi velvollisuutensa. Sitä tarkoittaen L. Onerva lauloi :

"Sun laulusi viestiäs kuljettaa, jos saarretaan airueet muut".

Alun alkaen esteettisiä tarkoitusperiä palveleva kirjallisuus voi ottaa herättäjäntehtävän sanomalehdistöltä omakseen siksi, että sensuurin paine ei kohdistunut siihen aivan yhtä ankarana kuin sanoma- ja aikakauslehdistooön. Sitä paitsi näyttää pikaisestikin asiaa silmäillen siltä, että ruotsinkielinen lehdistö ja kirjallisuus oli sensuurin vuoksi vieläkin suuremmassa ahdingossa kuin suomenkielinen. Kuitenkin painoviranomaiset rettelöivät jatkuvasti suomenkielistenkin kirjojen kustantajien kanssa viivyttäen kirjojen painatusta ja estäen jo painettujen teosten ilmestymistä. Sensuurin toimesta julkaistiin kiellettyjen kirjojen luetteloja, joihin vedoten ehkäistiin paitsi suomeksi ilmestyneen epäilyttävältä vaikuttavan kirjallisuuden myöskin rarsin vaarattomantuntuisen käännöskirjallisuuden levittäminen. Kirjakauppojen ja kirjastojen jatkurat tarkastukset. varmistivat sen, että määräyksiä myös noudatettiin. Tämän kirjoit-

\footnotetext{
5 Santeri Tvalo, Sortovuodet. Historian Aitta.

6 Santeri Tvalo, Sensuurioloista Suomessa. Oma Maa TT.
} 
taja totesi materiaaliaan kerätessään, että vuoden 1899 melko suorasti vihjailevat, rohkeat poliittiset allegoriat väistyvät vähitellen vuosien kuluessa yhä vaikeampiselkoisten tieltä: sellaisten, joiden allegoriikka ainakin näin lähes kuudenkymmenen vuoden jälkeen vaikuttaa melkein läpitunkemattomalta.

Ei siis ihme, että kahlehdittu sana, joka piti velvollisuutenaan herättää nukkuvia ja tukea ja rohkaista taisteluun heränneitä, pakeni vapaampaan ympäristöön. Mitä sanomalehdet eivät saaneet kotimaassa kertoa, se painatettiin Ruotsissa, josta lehtiä toimitettiin salateitse Suomeen. Runous, jonka sanoma ei aivan samassa määrin ollut sidottu päivän tapahtumiin kuin sanomalehden, pakeni kauemmaksikin. Tämän tutkielman aineistoon kuuluu neljä Amerikassa painettua runokokoelmaa. ${ }^{7}$ Tyypillinen emigranttirunoudelle on J. H. Erkon tapaus: vuoden 1903 lopussa Erkko jätti kustannusosakeyhtiö Otavaan runokokoelman. Sen tarkasti kustantamon toimitusjohtaja Alvar Renqvist, joka mielipiteenään ilmoitti runoilijalle, että kustannettavaksi tarkoitetussa kokoelmassa oli ainakin 15-20 runoa, jotka eivät tulisi menemään läpi sensuurin. Kun kokoelma sitten seuraavana vuonna julkaistiin nimellä "Ilmojen lauluja", siihen oli tehty melkoisia poistoja ja korjauksia. Karsimattoman kokoelman runoilija lähetti Amerikkaan maasta karkotetulle veljelleen Eero Erkolle, joka painatti runovihkosen nimellä "Hulluuksia" Suomessa salaa levitettäväksi. Se ehti ilmestyä vielä samana vuonna kuin "Ilmojen lauluja".8

Isä.nmaallinen runous on aina ollut olennainen osa runoutemme kokonaisuudesta. Erikoisesti 1800-luvun jälkipuoliskolla se oli voimakkaassa kasvussa; olisihan ollut ihme, elleivät Runebergin isänmaalliset tunnot olisi heijastuneet myös suomenkielisessä runoudessa. Joskus tämä runous kansallisista toiveista laulaessaan verhoutui allegorian vaippaan. Paavo Cajanderin "Vapautettu kuningatar" lienee tästä tunnetuin esimerkki. Mutta varsinaisten poliit-

7 J. H. Erkko, "Hulluuksia", Severi Nuormaa, "Elämän ulapoilla" (mol. ilm. 1904), Mikko Uotinen, "Hämärän hetkinä" (1908) ja Hilja Liinamaa, "Musta virta" (1913). Viimeksi mainittu kokoelma ei ilmestymisajastaan huolimatta ole tutkielmamme ulkopuolella, koska se-ilmeisesti sisältää vuosisadan alun poliittista runoutta, joka Suomessa ei saattanut päästä julkisuuteen.

s Vrt. Martti Jukola, J. H. Erkko II, s. 378 . 
tisten allegorioiden ensimmäiset merkit näkyvät runoudessamme vasta 1890-luvulla. Niiden alkaminen liittyy, kuvaavaa kyllä, saman vuoden tapahtumiin (1890), jolloin sanomalehdistömme sai kokea ensimmäisen sanan vapautta rajoittavan iskun. Tarkoitan tällä sanomalehti "Savon" lakkauttamista. Tuona vuonna Suomen postilaitos alistettiin Venäjän postilaitoksen alaiseksi. Larin-Kyöstin runo. "Postiruuna" on tiettävästi kirjoitettu paljon aikaisemmin kuin v. 1899, jolloin se julkaistiin kokoelmassa "Ajankäänteessä", ja kierrellyt sitä ennen monisteena kädestä käteen. Vakava, tehtävänsä hyvin täyttävä Suomen postiruuna, jonka laiskan postikonin kateelliset haltijat lyövät tainnoksiin, on poliittis-allegorisena kertomuksena tyypillinen sekä kokoelmalle "Ajankäänteessä" että ajan isänmaalliselle runoudelle vleensä.

1890-luvun laulajien, vuosisadan viimeisiä hetkiä lukuun ottamatta, ei ollut ehdoton pakko huolehtia allegorisen verhonsa tiiviïstä vedenpitävyydestä. Silti tapaamme tuoltakin ajalta allegorisesti verhottua poliittis-isänmaallista runoutta, vaikka verho usein. kin oli läpinäkyvä ja täydellinen verhottomuus paljon tavallisempaa. Erikoisesti pistävät silmiimme Severi Nuormaan runo "Revontulet", helmi Nuormaan muuten tasaisen harmaassa esikoiskokoelmassa (kirj. 1891), ja J. H. Erkon runot "Herliiläitä" ja "öljypuitten: alla", jotka on kirjoitettu v. 1898. Erkko oleskeli tuolloin Ranskassa ja oli nähtävästi paremmin informoitu Suomen asioista ja maatamme odottavista koettelemuksista kuin meillä kotona oltiin. Näissä "Valvojalle" lähetetyissä runoissa hän jo tietää paljon tulevaisuudesta: edellisessä hän näkee Suomen sotalaitosta uhkaavan lakkauttamisen, jota "tumma syöjä turilas" (= kenraali Kuropatkin) "herhiläisineen" ja "hiidenlintuineen" tavoittelee, ja jälkimmäisessä Bobrikovin tuliaispuheen todellisen arvon verraten sitä "hallaan myrkkyhuuleen", joka "syövyttää ja jäytää vuosisatain viljaa".9"Mutta. Suomesta käsin katsellen näyttivät oikeudenloukkaukset ja -rajoitukset vielä tuolloin tilapäisiltä ja ohimeneviltä. Kansallisiomanttisesti virittynyt sivistyneistömme luotti sinisilmäisesti Keisariinsa ja Perustuslakiinsa. Erkolla oli täysi syy laulaa:

9 Valvoja 1898 ja 1899. Tulkinnat Martti Jukolan, J. H. Erkko II, ss. $246-48$. 
Sinä lempeä, lauhkea suomalainen

kuin laps' olet luottava, uskovainen.

("He ja me", kirjoitusaika tuntematon, julk. Amerikassa v. 1904)

Tarvittiin todella räikeä isku vavahduttamaan kansamme hereille. Sellainen oli helmikuun manifesti. Manifestiin ja sen julkaisemisen synnyttämiin mielialoihin liittyviä allegorisia runoja ilmestyi siinä määrin, ettei olisi väärin puhua todellisesta runovyörystä. Jouluksi 1899 ilmestyi viisi runokokoelmaa, joissa huoli isänmaan kohtaloista kuulsi läpi allegorisen vaipan, ja arvattavaa — osaksi todistettavissakin — on, että useat v. 1899 kirjoitetut runot ilmestyivät vasta seuraavana vuonna tai seuraavina vuosina painetuissa kokoelmissa. Eräät runot näkivät julkisunden vasta vuosia myöhemmin, suurlakon jälkeen.

Sikäli kuin runot ovat dateerattavissa, on helmikuun manifestin johdosta ja tunnelmissa syntyneiden rarhaisimpien runojen aikajärjestys seuraava:

Eino Leino, Helsinki sumussa, kirj. 17. 2.189910

Larin-Kyösti, Näin unta, kirj. helmikuussa 1899

Hilja Liinamaa, Suomen miehen talvimietteitä, kirj. helmikuussa 1899

Eino Leino, Runoilija, kirj. helmikuussa 1899

Larin-Kyösti, Sudet tulevat, kirj. 4. 3. 1899

Eino Leino, Kansa kalliolla, kirj. 5. 3. 1899

Ilmari Kianto, Ne tahtovat, kirj. maaliskuun puolimaissa 1899

Larin-Kyösti, Saulin lankeemus, kirj. 19. 3.1899

Larin-Kyösti, Mihareppuri, kirj. 26. 3. 1899

J. H. Erkko, Sveitsi, kirj. huhtikuussa 1899

Edellisten 10 runon lisäksi kirjoittajan aineistossa on 38 poliittis-allegorista runoa, jotka ilmeisesti on kirjoitettu vuoden 1899 aikana, mutta joiden tarkempi dateeraaminen on kirjoittajalle mah-

10 17. 2. 1899 päivätty "Helsinki sumussa" on ilmeisesti ensimmäinen. Helmikuun manifesti painettiin 18.2. Virallisessa lehdessä ja 19.2. kaikissa Helsingin aamulehdissä. Leino lienee monien muiden kansalaisten tavoin saanut tie-tää manifestin sisällöstä etukäteen, joten runo on eräänlainen taiteellinen "varaslältö". 
dotonta. Kirjoittajina ovat edellisten lisäksi Hilja Haahti, Kalle Koski, Kasimir Leino ja Severi Nuormaa.

Seuraavina ruosina r'unojen tulva jatkuu. Larin-Kyösti tosin näyttää vaikenevan poliittisena runoilijana ja kääntyvän aiheisiin, jotka orat hänen runoilijanlaadulleen läheisempiä. Myöskin Hilja Haahden nimi häviää, mutta uusia runoilijoita kasvaa riveistä poistuneiden sijalle. Havaittavissa on myös, että vuosisadan vaihteen jälkeen kiristynyt sensuuri esti poliittisten tapausten käsittelemisen muutoin kuin kaikkein peitetyimmässä muodossa. Suurin osa vuosisadan vaihteen jälkeen kirjoitetusta poliittis-allegoriselta vaikuttavasta runoudesta ei liitykään — tai ei rohkene liittyä — mihinkään täsmälliseen tapaukseen tai ilmiöön, vaan kuvastaa tunnelmia ja mielialoja yleensä. ${ }^{11}$ Silloin käyvät hyvin harvinaisiksi ne runot, joissa runoilija kohdistaa allegoriaan verhotun vihansa nimenomaan henkilöön, siihen tai niihin, jotka olivat aiheuttaneet kansakunnalle tämän murheen ja häväistyksen. Lähinnä on tietysti Bobrikov apureineen, hänen jälkeensä ne senaattorit, jotka olivat äänestäneet manifestin julkaisemisen puolesta, myöntyväisyyssuunnan edustajat yleensä ja viime kädessä. itse keisari.

Selvimmin tulkittavat, sortotoimenpiteiden takana olevaan henkilöön kohdisturat allegoriset runot orat aikajärjestyksessä seuraavat:

.J. H. Erkko, Suuret lahjat, kirj. 1899

Ilmari Kianto, Pirulinna, kirj. 1899

Larin-Kyösti, Saulin lankeemus, kirj. 1899

Larin-Kyösti, Näin unta, kir.j. 1899

J. H. Erkko, Pienten sankari, kirj. 1899 tai 1900

Paavo Cajander, Ahab ja Nabot, kirjoitusaika tuntematon, julkaistu kokoelmassa "Runoelmia" 1914. Kaikesta päätellen runo on dateerattava vuoden 1900 tienoille.

Paavo Cajander, Leivo ja haukka, kirj. 1902

Kössi Lindström (Kaatra), Belzatsar juhlii, kirj. 1904 tai 1905

Hil.ja Liinamaa, Nero, kir.j. 1908

Tässä yhteydessä huomautettakoon, että useimpien tämän kaltaisten runojen tulkinta kilpistyy mahdottomuuteen sanoa, onko runoilija tarkoittanut korkeimman määräysvallan omaavalla sortajallla keisaria vai kenraalikuvernööriä. Kumpaankin suuntaan käy-

11 Ilmiö näkyy selvänä kaikkialla muuallakin eikä vain runoudessa. 
viä tulkintoja on vuosikymmenien varrella esitetty. Kirjoittaja puolestaan esittäisi omana subjektiivisena näkemyksenään, että yllä olevan luettelon ensimmäinen, toinen, seitsemäs ja yhdeksäs runo kohdistuvat Bobrikoviin ja muut Nikolai II:een.

Eugen Schauman ja hänen urotekonsa näkyy rain kahdessa aineiston runossa:

Aarni Kouta, Cola di Rienzi, kirj. 1904

J. H. Eirkko, Sinä, kirj. 1904

Niin allegorisesti verhottuja kuin nämä runot ovatkin, pääsivät ne julkisuuteen vasta sitten, kun suurlakko oli murtanut sensuurin kahleet (1905 ja 1906). Bobrikovin murhaan viittaa myös Hilja Liinamaa edellä mainitsemassamme runossa Nero. Runojen lukumäärän niukkuudesta päätellen tapaus ei ilmeisesti tarjonnut sytykettä runoilijoillemme, sillä poliittinenkin murha on murha ja sellaisena kansamme luonteelle vieras ja hätkähdyttävä. Ei edes Eugen Schaumanin uhri voinut sitä kirkastaa runoilijoille sytyttäväksi aiheeksi.

Seuraavat aineiston runot ovat nähdäksemme kirjoitetut sananvapauden puolesta ja eräät niistä ilmeisesti tietyn sensuurin toimenpiteen johdosta :

J. H. Erkko, Alas vääryys, kirj. 1899

Eino Leino, Vapaa sana, kirj. 1899 tai 1900

Hilja Liinamaa, Vapaalle sanalle, kirj. 1899 tai 1900

Eino Leino, Mykkä laulaja, kirj. 7. 11. 1900

J. H. Erkko, Herra meitä varjele, kirj. 1903

Myöntyväisyyssenaattoreihin, -suuntaan ja yleensä toisinajatteleviin kansalaisiin kohdistunut allegoriikka on kaikkein räikeimmässä muodossaan tavattavissa J. H. Erkolla. Hänen runollaan "Pensaita ja puita", kirj. 1899, on tietty olemassaolonoikeutensa kansansa sisäisten ristiriitojen kuvastajana, mutta v. 1903 kirjoitetut ja v. 1904 kokoelmassa "Hulluuksia" julkaistut runot, sellaiset kuin "Mielen mato", "Viel' onko ken järjessään", "Myrsky hullujen huoneessa", "Kauhutauti", "Eksyttäjille" jne. ovat kaikkein matalimman luokan häväistysrunoutta, jotka eivät kohoa korkeammalle kuin purkamaan vihaa poliittisia vastustajia, "matelijoita", "ryömijöitä", :"nuoleksijoita", "synkän vallan syöttiläitä" jne. vastaan.

Kirjoittaja on näin saanut noin viidenneksen aiheistoonsa kuuluvista runoista sijoitetuilssi jonkun määrätyn tapahtuman, ilmiön tai 
henkilön yhteyteen. Noin puolet tästä viidenneksestä on kirjoitettu. käsiteltävänä olevan ajanjakson ensimmäisenä vuonna, v. 1899. Mainitun vuoden jälkeen käy runon täsmällinen sijoittaminen vuosi vuodelta yhä vaikeammaksi. Kirjoittaja luopuu yrityksestäkin, ettei. joutuisi katteettomien arvailujen hyllyvälle suolle.

Aluegoriset kUvat. Kerätty materiaali todistaa, että valtaosa poliittisen runouden allegorisista kuvista on saatu luonnosta. Tähän on olemassa yksinkertainen selitys: luonto ilmiöineen, vuoden- ja vuorokaudenaikojen vaihtelu, eläin- ja kasvikunnassa käytävä taistelu olemassaolosta jne. tarjoaa lukemattomia kouriintuntuvia esimerkkejä vastakohtaisuuksista ja voimakkaamman häikäilemättömästä käyttäytymisestä vähäisempää kohtaan. Erikoisesti käytetään luonnon kuvien tarjoamaa allegoriikkaa poliittista sortoa ja sortajaa symbolisoitaessa. Synkät säät, vaaralliset luonnonilmiöt, pahimmat vihollisemme eläinkunnassa, sanalla sanoen kaikki, mikä uhkaa, vaikeuttaa tai tuhoaa karun maan asujaimen jokapäiväistä elämää ja toimeentuloa, projisioidaan sortoon ja sortajaan. Kaikkein useimmissa tapauksissa myös positiiviset, puolustettavat arvot symbolisoidaan luonnonilmiöillä, kaikella sillä, mikä on omaa, turvallista, hyvää, hyödyllistä ja mieltä ilahduttavaa. Joissakin tapauksissa tämän positiivisen puolen symbolit on haettu kulttuurielämän ilmiöistä ikään kuin korostamaan henkisen tasomme etevämmyyttä sortajan tasoon verrattuna: kirja, Raamattu, laki, touko, äiti, kannel tai karja ovat joskus, vaikkakin harvemmin, niitä arvoja, joita itätuuli uhkaa ja joita on miehuullisesti puolustettava.

Käsiteryhmä "myrsky", "tuuli", "viima", "tuisku" on aineistossa. useimmin esiintyvä alkavaa (tai jatkuvaa) sortoa ilmentävä kuva. Sen on ensimmäisenä tuonut sortoajan xunouteen Eino Leino runossaan "Kansa kalliolla" (5.3.1899). Jo samana vuonna tapaamme sen kaikkien muidenkin auktorien poliittis-allegorisessa runoudessa, eikä kirjoittajan materiaalissa ole ainoaakaan runoilijaa, joka ei sitä olisi käyttänyt. Usein symboli esiintyy yhdyssanan jälkiosana; etuosana on silloin myrskyn, tuulen jne. suuntaa tai ikävää laatua ilmoittava sana (esim. itämyrsky, itätuuli, kaakkoismyrsky, kaakkoistuuli, syysmyrsky, talvimyrsky). Joskus symboli saà attribuutin (esim. idän viima, Viron viimat, talven tuisku, armoton myrsky, vinkura viima). Oikeutemme, jota myrsky jne. koettelee, on "honka", 
"'kallio", "koivu", "kukka", "laiva", "metsä" tai "puu".12 Myrskyn jne. voittaa "aurinko", "kevät", "kesä", "suvi", joskus myös "pohjatuuli" (contra "idän viima").

Lukumääräisesti melkein yhtä suosittu on käsiteryhmä "talvi", "halla", "pakkanen" kuvaamassa sortotoimenpiteiden aiheuttamaa jähmettynyttä hämmästystä ja kauhistusta maassamme ja niiden vaikutusta kansalliseen elämäämme. Tätä symbolia ovat ensimmäisinä käyttäneet Eino Leino runossa "Runoilija" ja Hilja Liinamaa runossa "Suomen miehen talvimietteitä", jotka molemmat ovat päivätyt helmikuulle 1899. Mahdotonta on selvittää, kumpi runoilijoista tässä kilvassa on ollut ensimmäinen, eikä sillä tiedolla olisi mitään merkitystäkään. Yhdyssanan jälkiosanà esiintyy materiaalissa vain "halla" (yöhalla); attribuutilla varustettuna tapaamme käsiteryhmän sanan useammin (idän halla, kaakon halla, armoton talvi, halla, pakkanen, hyytävä halla, tuima talvi). Talvi yrittää voittaa "kevään", "kesän", "suven"; halla ja pakkanen yrittävät panna "kukan", "oraan", "pellon", "touon", "viljan".13

Käsiteryhmä "yö", "pimeys", "pimeä", "hämärä", "hämäryys" ilmestyy symbolina poliittiseen runouteemme v. 1899 siinä määrin yht'aikaa ryöpsähtäen, ettei sen keksijää voitane määritellä. Tietysti tämä symboli on, samoin kuin edellisetkin, hyvin helposti runoilijalle tarjolla, joten se on hyvinkin voinut syntyä samanaikaisesti useissa aivoissa. Tässä yhteydessä sopii kuitenkin panna merkille, että Eugen Wolff käytti "yö"-symbolia maankuulussa puheessaan, jonka hän piti ministerivaltiosihteeri Procopélle maaliskuun puolimaissa 1899 Pietarissa Suuren Lähetystön nimissä. ${ }^{14}$ Mahdollista on. että symboli on peräisin mainitusta puheesta, varsinkin kun kirjoittaja ei ole löytänyt ainoatakaan ennen huhtikuuta 1899 kirjoitettua runoa, jossa "yö" olisi symbolisoinut helmikuun manifestia taikka mitään muutakaan maahamme kohdistunutta sortotoimenpidettä.

12 Severi Nuormaan runossa "Laiva merellä" (1900) on vertaus päinvastainen. Ylväs laiva edustaa sortajaa, jonka sitkeät ja väsymättömät pijkku aalIot kukistavat.

13 Eino Leinon runossa "Helsinki helmilöissä" (1901) ja Severi Nuormaan ruinossa "Pakkastoiveita" (1899) esiintyy pakkanen positivisena arvona (contra sumu).

14 "Semmoista hallayötä kuin helmikuun 15. päivä Suomen kansa ei vielä koskaan ole nälınyt". Suomen kansan ailiakirjat VIII s. 606. 
Symboli tuli jo ensimmäisenä vuonna hyvin suosituksi. Aineistossamme sen frekvenssi on yhtä suuri kuin "talvi"-ryhmän ja vain hieman pienempi kuin "myrsky"-ryhmän. Jälkiosana se esiintyy yhdyssanassa hallayö. Siihen liittyy joukko kuvaavia attribuutteja (esim. musta yö, sankka yö, pimeys, synkkä yö, hornan yö, kalman yö). Oikeuttamme esittävänä arvona on luonnostaan lankeavan "päivän” lisäksi "kajastus", "kajo", "rusko". Yön jne. voittaa "aamu,", "aurinko", "päivä", "päivännousu".

"Sumu"-symboli, jolla Eino Leino aloitti kautemme poliittisallegorisen runouden (Helsinki sumussa 17. 2.1899) löysi vain vähän seuraajia. Nähtävästi runoilijamme olivat sitä mieltä, että Leinon allegorinen kertomus Helsinkiin leviävästä ja kansalliset ylpeydenaiheet vähitellen saartavasta sumusta oli käyttänyt tämän allegorian keinot loppuun. Hilja Haahdella tapaamme kerran symbolin "usva"" ja Ilmari Kiannolla ja Eino Leinolla "usma".

Larin-Kyöstin runosta "Sudet tulevat" (kirj. 4. 3. 1899) on nähtävästi lähtöisin symboli "susi". Larin-Kyösti suosi runoudessaan tätä kuvaa, mutta emme voi sanoa sen yleistyneen. "Suden" lisäksi hänellä on myös "liurtta" varsin tavallinen. Eino Leinolla tapaamme symbolin "hukka" ja J. H. Erkolla "aron hukka".

J. H. Erkon runossa Vuosisatain vaihteessa (kirj. 1. 1. 1900) käytetään sortajasta kuvaa "myrkkyä keittävä käärme". Kuva ei tullut enemmälti suosituksi. Mikko Uotisella ja Severi Nuormaalla huomaamme symbolin "kyy", viimeksi mainitulla myös "mato". Hil.ja Liinamaalla näemme symboliparin kontio-karja. J. H. Erkolla on sortaja kerran "karhu", mutta toisen kerran "karhu" on positiivinen arvo contra "susiparvi" (Miesten laulu).

Har'vemmin käytettyjä kuvia ovat (suluissa ensimmäisen kävttäjän nimi) sorrosta: "kahleet" (L. Onerva), "kulo" (Larin-Kyösti), "raekuulo" (Hilja Haahti), "rajuilma" (Hilja Haahti), "sade" (Eino Leino), "tulva" (Ilmari Kianto), "ukkonen" (Hilja Haalti), sortajasta: "haukka" (J. H. Erkko), "poppa" (Larin-Kyösti), "rosvot" J. H. Erkko), "varkaat" (J. H. Erkko), sananvapaudesta: "koppiin teljetty kotka" (Hilja Liinamaa), "kuu, tähdet" (.J. H. Frkko), "laulaja" (Eino Leino) ja "soihtu" (J. H. Erkko).

Loppupäätelmänä on sanottava, että poliittisen runouden allegoriset kuvat, vaikka määrältään loppumattomat, eivät tarjoa suurta vaihtelua. Suositut, hyvin ahtaasta piiristä haetut kuvat ovat lop- 
puun asti kulutettuja. Sitä ei kuitenkaan tarvitse ihmetellä, kun muistamme, että kaikki tarkastelemamme runous on kirjoitettu yhtä ainoata tarkoitusta varten, tarkoituksena herättää, herättää . . . Sivistyneistö, kaupunkilaiset ja kaupunkien järjestynyt työväki olivat jo heränneet. Työ oli siis kohdistettava maaseudulle, sana oli saatava. kaikumaan kansakoulujen katedereista ja kaukaisten maankulmien. nuorisoseurajuhlien lausujankorokkeelta, minne sanomalehdistön vaikutusvalta ei yltänyt ja missä lukutaidonkin laita oli vanhemman polven keskuudessa hieman niin ja näin. Kirjoittajan käsityksen mukaan siitä johtuu tämän runouden yksipuolinen kuvien valinta. ja itse poliittisten probleemien konkretisoiminen ja pelkistäminen hyväksi ja huonoksi, valkeaksi ja mustaksi. Sellaisesta runoudesta. on runouden hienoin tuoksu tietysti poissa eikä sille voi ennustaa. pitempää kuin päiväperhosen ikää, mutta historiamme todistaa, että. se lyhyenä elinaikanaan täytti tehtävänsä.

AlLegoriset KeRTOMARUNot', jotka aineistoomme sisältyvät, ovat: frekvenssijärjestyksessä. luetellen seuraavilta neljältä alalta: Raama-tusta, historiasta; Kalevalasta ja luonnosta.

Raamatusta saadut kertomukset ovat syntymis- (julkaisemis-). järjestyksessä seuraavat:

Larin-Kyösti, Saulin lankeemus, kirj. 9. 3. 1899. Saul = keisari.. Runoilija on vahvasti mukaillut Raamatun kertomusta, jotta sortokauden alun huomattavimmat tapaukset, mm. keisarin kieltäytyminen ottamasta vastaan ns. Suurta lähetystöä, mahtuisivat kertomuksen kehyksiin. (I Sam. 13-16)

Eino Iseino, Molok, kirj. 4.4. 1899. Molok = Venäjän sotalaitos, "raudasta rakennettu, hehkuva-helma, suu suden, pää pedon kauhistavan". Raamatullista kertomuksessa on vain nimi Molok, jolle kiel-. letään uhraamasta lapsia. Runo liittyy Suomen sotalaitokseen kohdistettuiluin laittomuuksiin. (III Moos. 18:21 ja 20:2)

Severi Nuormaa, Ziion, kirj. 1899. Ziion = Suomen kansa. Kertoen Israelin lasten koettelemuksista Baabelin vankeudessa runoilija. kuvaa sorron aiheuttamia tunnelmia. Runon alussa on maininta: "Aihe vuodelta 586 e. Kr. Mainittuna vuonna Nebukadnesar valloitti Jerusalemin." (II Kun. 25 ja 26; II Aik. 36)

Ilmari Kianto, David, kirj. 1900. David $=$ Suomen kansa. Davidin epätasainen taistelu Goljatia vastaan on varmaan erinomainen 
symbolisoimaan oikeustaisteluamme; merkillıstä vain, että vertausta ei ole enemmän käytetty. (I Sam. 17:25-)

J. H. Erkko, Pienten sankari, kirj. 1900. Allegoria Uuden Testamentin kertomuksesta siitä, kuinka Herodes = keisari (Bobrikov?) halusi tappaa Jeesus-lapsen =- Suomen itsemääräämisoikeuden. (Matt. $2: 16$ )

Paavo Cajander, Ahab ja Nabot, kirj. 1902. Kuningas Ahab = keisari (Bobrikov?) haluaa omakseen jisireeliläisen Nabotin viinitarhaa, joka on hänen palatsinsa vieressä. Nabot $=$ Suomen kansa ei suostu antamaan isiensä perintöosaa. (I Kun. 21)

Severi Nuormaa, Simson, kirj. 1903. Simson = Suomi, filistealaiset $=$ sortajat. Simson tuhoaa kiusaajansa ja tuhoutuu itsekin samalla voitokkaan varmana siitä, ettei "rapaa orjana kuolla saa, hän on surmansa hetkellä suurin". Sortotoimenpiteitä kuvatakseen Nuormaa on liittänyt omaan kertomukseensa Raamatun kertomukselle vieraitakin aineksia. (Tuom. 16)

Severi Nuormaa, Jisraelin vanhimmat, kirj. 1903. Runo seuraa vapaasti samaa Raamatun kertomusta kuin yllä mainittu Paavo Cajanderin runo. Raamatun kertomuksen vastaisesti alamaisen nimi on Nabot pro Nabob. (I Kun. 21)

Kössi Lindström, Tietäjät, kirjoitusaika tuntematon, julk. 1904. Tietäjät $=$ oikeuden etsijät ja puolustajat. Raamatun kertomusta suuresti laajennettu. Muutoinkin allegoria vaikuttaa kovin kaukaa haetulta. (Matt. 2:1-12)

Aarni Kouta, Kainin merkki, kirjoitusaika ehkä 1903-04, julk. 1905. Kainin merkki = orjuus, jolıon sortaja pakottaa vapaan kansan. Allegoria epäselvä. Runo rajatonta uhmaa ja vihaa uhkuva. (I Moos. 4:1-16)

Kössi Lindström (Kaatra), Belzatsar juhlii, kir.j. 1903-04. Belzatsar (Belsassar ${ }^{*}$, Baabelin kuningas = keisari, sureva kansa = suomalaiset. (I)an. 5: 30)

Kössi Lindström (Kaatra), Simson, kirjoitusaika tuntematon, kaikesta päätellen v. 1904, julk. 1906. Vrt. yllä Severi Nuormaan Simson. (Tuom. 16)

Mikko Uotinen, Abel, kirjoitettu luultavasti 1904, julk. 1908. Abel = Suomen kansa, Kain = sortaja. Allegoria erittäin luonteva varsinkin verrattuna yllämainittuun Koudan runoon Kainin merkki. (I Moos. 4:1-16) 
Hilja Liinamaa, Niinkuin Simson, kirjoitettu nähtävästi aivan vuosisadan alussa, päässyt julkisuuteen Amerikassa vasta v. 1913. Vrt. yllä Severi Nuormaan Simson. (Tuom. 16)

Historiasta saadut allegoriset kertomukset tuovat ahdistetun kansan silmien eteen suuria historiallisia esikuvia, kuvia henkilöistä, jotka osasivat täyttää velvollisuutensa, ja oloista, jotka olivat ehkä vieläkin vaikeampia kuin Suomen. Aineistoon sisältyvät historiasta saadut kertomukset ovat syntymis- (julkaisemis-) järjestyksessä seuraavat:

J. H. Erkko, Sveitsi, kirj. 3. 5. 1899. Runossa Erkko asettaa rinnakkain Sveitsin perinnäisen vapauden ja Suomen kantamat kahleet. Erkolle epätavallinen alakuloinen sävy korostaa vertailun räikeyttä. Runoilija oli edellisenä vuonna viettänyt pitkähkön ajan Sveitsissä telvveyttään hoitamassa ja nähnyt siellä, kuinka pienikin kansa menestyy ja kukoistaa vapaudessa. Havainto antoi aihetta moniin muihinkin runoihin.

Eino Leino, Kartagon nainen, julk. 1902. Runo, joka korostaa naisen osuutta yhteisessä puolustusrintamassa, on ehkä pantava yhteyteen näinä aikoina yleistyvän naisasia-aatteen kanssa. Viittaus Sveitsin kansallissankariin Arnold von Winckelriediin antaa epäämättömän todistuksen runon poliittisesta luonteesta.

Severi Nuormaa, Andreas Hofer, kirj. 1902. Nimihenkilö on tyrolilainen kapinanjohtaja v:lta 1809 ja kansan — ja runoilijan käsityksen mukaan vapauden esitaistelija tyranniaa vastaan. Samassa runossa runoilija kohottaa sorrettujen suomalaisten näkyviin myös Winckelriedin, Wilhelm Tellin ja Jeanne D'Arcin.

Aarni Kouta, Cola di Rienzi, kirj. 1904 Bobrikovin murhan ja Eugen Schaumanin isänmaallisen teon tunnelmissa. Nimihenkilö, Nicolas di Rienzi oli Rooman tribuuni ja v:n 1347 kapinan johtaja, mies, joka ei kavahtanut ottaa vastuuta ja toimia toisten epäröidessä.

Aarni Kouta, Patriisi puhuu, kirjoitettu kaiken todennäköisyyden mukaan ennen suurlakkoa, julk. 1907. Aimo Hakasen mukaan "herjattu Rooma näyttää symbolisoivan sitä vanhaa valtion ideaa, jonka tilalle uuden valtiopäiväjärjestyksen mukaan oli syntymässä toinen".15 Tämän kirjoittaja pitää tulkintaa älykkäänä ja täysin oikeaan osuvana.

15 Proseminaariesitelmä Turun Yliopistossa keväällä 1959 (painamaton). 
Aarni Kouta, Kuolemaan vihityt, julk. 1905. Leonidaan spartalaiset manataan runossa esiin esimerkiksi Suomen aktjiviselle vastarintaliikkeelle.

Hilja Liinamaa, Galeriorjat, kirjoitusaika tuntematon, ilmeisesti kuitenkin ennen suurlaklkoa. Pääsi julkisuuteen Amerikassa vasta v. 1913. "Galeriorjat", jotka viimeisin voimin kiskovat raskasta. purtta = suomalaiset; Rooma, armoton käskijä, joka viuhuttaa ruoskaansa onnettomien orjien pään päällä = Venäjä. "Mut tietäkää, loppunsa kaikella. Ja kerran Roomakin maassa makaa _."."

Hilja Liinamaa, Nero, kirjoitusaika tuntematon, mutta varmasti Bobrikovin murhan jälkeen ja otaksuttavasti ennen suurlakkoa, julk. Amerikassa v. 1913. Nero, "hirmutyranni" = Bobrikov.

Kalevalasta saatu allegorinen kertomus ei aineistomme todistuksen mukaan esiinny läheskään niin runsaana kuin olisi voinut olettaa. Miksi asianlaita näin on, siihen seikkaan palaamme myöhemmin. Aineistossamme on seuraavat kolme esimerkkiä Kalevalan pohjalla luodusta allegorisesta kertomuksesta:

Severi Nuormaa: Loviattaren lapset, kirj. mahdollisesti 1899, julkaistu 1900. Kysymyksessä on 9 runon sikermä, ilmeisesti suurisuuntaiseksi tarkoitettu yritys kuvata kansamme vaiheita, vaikkakaan tulos ei vastaa tarkoitusta. Louhi $=$ Venäjä kadehtii Kalevan kansaa = suomalaisia, jotka sitkeydellään ja uutteruudellaan ovat saaneet maansa kukoistamaan. Kalevan kansan päämies Väinämöinen herättää lopuksi kansan voiman ja kunnon voittamaan Louhen loihdun.

Eino Leino, Laulu valon sodassa, julk. 1901. Epäluulojen välttämiseksi runoilija on lisännyt "selityksen": "Kun Kalevan sankarit ennen muinen valon sotaan suorivat, kerrotaan heidän ennen lähtöään marssineen Ukon puun ympäri laulaen seuraavaa laulua." Kuvat ovat samat kuin edellisessä. Kalevan kansa = suomalaiset, Louhi, jonka vankina päivä makaa $=$ Venäjä.

Laura Soini, Kullervo hirsimetsässä, julk. 1905, kirjoitettu ilmeisesti edellisen vuoden alussa. "- - - se, että rikkaasta kansanrunoudestamme valitaan Kullervo tarinan aiheeksi", saa Marja Nymanin ensi sijassa aavistelemaan runon poliittista allegoriikkaa.16 Lähtökohta on epäilemättä oikea. Kullervon heimo = Suomen kansa

16. Proseminaariesitelmä Turun Yliopistossa keväällä 1959 (painamaton). 
ja Untamo = sortovalta, joka peitti ja tukahdutti elämän levittämällä kaikkialle metsänsä naavaiset lehvät ja lonkerot. Kullervo taistelee heimonsa oikeuksien puolesta iskien maahan kaiken, mikä estää aurinkoa paistamasta.

Luonnosta saatu allegorinen kertomus jää materiaalissamme lukumäärältään vähäisimmäksi. Syynä siihen on se, että luonto, joka tarjoaa taiteilijalle suorastaan lukemattoman määrän kựia, ei ole suinkaan yhtä altis kertomusten lähde. Sitä paitsi raja allegorisen kuvan, kuvasarjan ja kertomuksen välillä on hyvin epämääräinen, nimenomaan mitä luonnon antamaan aiheistoon tulee. Kun kirjoittaja on vetänyt tämän rajan siten, että kuvien joukkoon on laskettu kaikki runot, mitkä suinkin antavat mahdollisuuden tällaiseen tulkintaan, jää materiaaliin allegorista luonnonaiheista kertomusta edustamaan vain kaksi runoa: yllä käsitellyn Eino Leinon runon "Helsinki sumussa" lisäksi vain Larin-Kyöstin "Näin unta", kirj. 1899. Runon minä, hyönteiskansan hallitsija = keisari; hänen alamaisistaan heinäsirkat, sudenkorennot ja sääsket = venäläiset, muurahaiset $=$ suomalaiset. Kiven heittäminen, muurahaispesän sytyttäminen ja hajallepotkiminen $=$ sortotoimenpiteet; muurahaisten hyökkäys keisarin kimppuun = vastarinta. Vain sensuurilaitoksen keskeneräisyys v. 1899 selittää sen, että tämä rohkea ja sattuva poliittis-allegorinen runo saattoi päästä julkisuuteen. Jo vuotta myöhemmin se olisi ollut mahdotonta.

Raamattuun perustuvat allegoriset kertomukset edustavat siis kerätyssä materiaalissamme suurinta ryhmää. Lukumääräisesti se on vhtä vahva kuin muut ryhmät yhteensä. Vaikka - kuten aikaisemmin olemme huomauttaneet — materiaalin keruu, toisten runojen mukaanotto ja toisten poisjättäminen, on hyvin suuresti subjektiivisten käsitysten ja tuntojen varassa, näyttää kuitenkin siltä, että tämä allegoristen kertomusten laatusuhde pysyy suunnilleen samana riippumatta siitä, onko materiaali laskettu tiheämmän vai harvemman seulan lävitse. Raamatullisten kertomusten suosituimmuus on helposti selvitettävissä: herätystyön kohdistuessa lähinnä maaseudulle oli kertomukset valittava sellaisesta piiristä, joka oli tutuinta ja josta ne helpoimmin olivat projisioitavissa oleviin oloihin. Kun lụonto käsittääksemme ei tarjonnut kertomusmateriaalia - kuvien suhteen on asianlaita aivan toinen - haettiin se Raamatusta, joka vuosisadan alussa oli varmasti tunnetuin ja luetuin kirja kansamme 
keskuudessa. Maaseudun vanhemman polven opinkäynti supistui yleensä rippikouluun, ja vihkimälahjaksi saatu Raamattu oli kaikkein useimpien kotien ensimmäinen - ellei ainoa - kirja. Historiasta ja Kalevalasta otetut allegoriset kertomukset vetosivat kai lähinnä sivistyneistöön. Siksi korkealta ne ampuivat maaseudun rahvaan pään ylitse.

Jo aikaisemmin olemme huomauttaneet, että poliittis-allegorisen runouden taiteellinen taso ei kokonaisuutena katsoen ole korkea. Yksityisten runoilijoiden kohdalta on tehtävä samankaltainen havainto: vain joissakin erikoistapauksissa voidaan tähän ryhmään kuuluvan runon katsoa edustavan tekijänsä tuotannon arvokkaampaa puolta. Silloin näyttää olleen kysymyksessä äkillisesti lyyrilliseksi runoksi purkautuva voimakas tunne, suru, loukattu. oikeudentunto, raivo, kostonhimo tms. Tällaisetkin tunteet voimakkaasti elettyinä ja äkillisesti purkautuvina näyttävät voivan olla se tunnepohja, josta runo kasvaa esiin. Sen sijaan tämänkaltainen tunne pitkään haudottuna, kirjallisesti huolitellusti muotoiltuna ja tietyn tendenssin yhteydessä esiintuotuna ei ulotu korkeihin taiteellisiin tuloksiin.

Suomalaiselle mentaliteetille vieras ja siksi isänmaallisessa runoudessammekin ylen harvinainen koston ajatus pilkahtaa silloin tällöin esiin käsittelemämme kauden poliittis-allegorisessa 1yriikassa. Kostonhalu ei kohdistu vain sortajana nähdyn henkilön persoonaan, vaan koko sortojärjestelmään ja suureen kansaan, joka yrittää musertaa pienen. Keräämäämme aineistoa tarkastellessamme huomaamme koston ajatuksen- olevan läheinen juuri niille runoilijoille, joiden allegoriset hyökkäykset ovat rohkeimmat ja rajuimmat ja jotka tuntevat läheistä hengenheimolaisuutta aktiivisen vastarintaliikkeen kanssa.

Tässä yhteydessä on huomautettava, ettei runoilijan isänmaallista mieltä voida mitata sen mukaan, osallistuuko hän sortovaltaa vastaan käytävään poliittiseen kampanjaan kynänsä avulla vai ei ja minkä aktiviteetin määrän hän kehittää. Ratkaisevia ovat itsekunkin runoilijan perustunnot, hänen sielunsa sisäinen maisema, jolla voi olla kosketuskohtia ulkopuolella pauhaavan arkielämä̉n kiistoihin, mutta josta yhtä hyvin nämä kosketuskohdat voivat puuttuakin. Edellisessäkin tapauksessa hänen suhtautumistapansa voi määräytyä monien muiden epäolennaisilta näyttävien seikkojen mukaan. Kerää- 
mässämme materiaalissa edustavat Hilja Haahti ja J. H. Erkko kahta äärimmäisyyttä. Kumpaankin ovat maatamme kohdanneet sortotoimenpiteet vaikuttaneen järkyttävästi; siitä ovat heidän runonsa puhuvina todisteina. Mutta kun edellinen kehottaa kansaansa. nöyrtymään, tyytymään ja paremman päivän toivossa turvaamaan Jumalan armoon, kohottaa jälkimmäinen ilmoille raivoa ja vihaa uhkuvia huutoja sortajaa vastaan ja - olosuhteiden pakosta tosin epäsuorasti - yllyttää aseelliseen vastarintsan. Välittävänä renkaana näiden kahden vastapoolin välillä kirjoittaja näkee Eino Leinon, joka ulospäin kääntyneistä kuohahteluistaan huolimatta eli sijaiskärsijänä kansansa vaikeat vuodet.17

Seikka, joka ei roi olla liikuttamatta runsaan puolen vuosisadan takaison runouden lukijaa, on se, että huolimatta erilaisesta suhtautumistavastaan sortovaltaan ja sen ilmiöilin jokainen vuosisadan vaihteen ja alun runoilija pystyy loppujen lopuksi säilyttämään uskonsa oikeuden lopulliseen voittoon. Raivon ja nöyrtymyksen, uhman ja tyytymisen takaa kuultaa lopullinen utopistinen päämäärä: vapaa, riippumaton ja itsenäinen isänmaa.

Lopuksi pyydän lausua vilpittömän kiitokseni Turun Yliopiston kotimaista kirjallisuutta kevätlukukaudella 1959 opiskelleen proseminaariryhmän jäsenille, tässä mainituille ja mainitsematta jääneille. Erikoisesti lähteiden hakemisessa heidän esitelmänsä ovat olleet kirjoittajalle suureksi avuksi.

\section{Kauko Kyчrö: Political Allegories in Finnish Poetry between the February Manifest and the General Strike}

The material used by the present writer consists of 148 lyrical and epic poems written in the period February 1899-October 1905. Patriotic poetry has always been an essential part of Finnish poetry. In the 19th century it only rarely had an allegorical form. When the period of oppression began in February, 1899, the advance censorship of materials to be printed became extremely strict. This is especially true of the censorship of newspapers. In these eireumstances poetry took over from newspapers the task of awakening the nation. As early as 1899 all poetry had to be veiled as allegory if it were to be published. The allegories of the year 1899 are nevertheless rather transparent,

17 Vrt. Lauri Viljanen, Eino Leino vapauden runoilijana, 'Turun Sanomat No 175 v. 1953. 
but year by year the veil became more opaque. The present witer finds that the degree of allegory in the political poetry is directly proportionate to the increasing strictness of the censorship.

This type of didactic poetry was primarily intended for the rural population, which was less conscious of political matters than were the inhabitants of towns. This is why the allegorical images were taken almost exclusively from nature and its phenomena, and the allegorical stories were taken mostly from the Bible, which at the beginning of this century was still the best known literary work in the rural districts of Finland. The allegorical images are almost exclusively aimed at the oppression as a whole, but the allegorical stories are often aimed also at the oppressor, the Emperor or Governor General Bobrikov. The various degrees of restraint and outspokenness in the poets throw a great deal of light on their individual psychologies.

The poetry of political allegory does not represent the best part of poetry. There is a clear tendentiousness in place of aesthetic values. Only very few of these poems have proved to be fit to survive. But we have to keep it in mind that they are to be regarded primarily as relics of difficult years in the history of the Finnish people. 